\title{
THE EFFECT OF CARBIDES ON THE KINETICS OF BAINITIC TRANSFORMATION AND THE RESULTING NANOBAINITIC MICROSTRUCTURE IN 90SiCrMn6-4 STEEL
}

\author{
Karolina SZWEJKOWSKA, Magdalena BAGROWSKA, Krzysztof WASIAK, Emilia SKOŁEK, \\ Szymon MARCINIAK, Wiesław ŚWIĄTNICKI
}

Faculty of Materials Science and Engineering, Warsaw University of Technology, Warsaw, Poland, EU karolina.zadrozna@nanostal.eu

https://doi.org/10.37904/metal.2019.720

\begin{abstract}
The aim of the work was to determine the influence of the quantity and distribution of carbides on the bainitic transformation process that takes place in 90SiCrMn6-4 steel. The kinds of possible carbides that can be formed in steel and the kinetics of their precipitation were examined by the use of computer simulations. Various thermal treatments, leading to obtaining of different size and distribution of carbides in steel, were carried out. The obtained microstructures were studied by the use of Light Microscopy (LM) and by Transmission Electron Microscopy (TEM). The pre-heat-treated steel samples with different carbide size and distribution were subjected to austempering processes. The kinetics of bainitic transformation in samples with different carbide size and distribution were analysed by means of dilatometric tests and the resulting microstructures were examined by use of TEM. The obtained microstructure was composed of carbide free bainitic matrix in which carbides were observed. Thickness of the bainitic ferrite plates and austenite layers, in samples with different carbide distributions, was measured. Finally, hardness of the heat treated samples was determined.
\end{abstract}

Keywords: Steel, bainitic matrix, carbide precipitations, nanostructuring process

\section{INTRODUCTION}

An effective method used to ensure high hardness and plasticity in steels is the reduction of the size of phase grains. Other methods that improve hardness lead to diminishing of plasticity of steel. This effect significantly reduces suitability of such steels in many applications [1-4]. Unprecedented combination of high strength, fracture toughness and ductility was obtained in a new generation of nanobainitic steels [5]. A nanobainitic microstructure can be achieved in steels containing an increased content of carbon $(0.6 \div 1.1 \mathrm{wt} . \%)$ and silicon (c.a 1.5 wt.\%) by the use of specially designed heat treatment This treatment consists of the following steps: austenitization, followed by rapid cooling to the temperature lying in the lower range of the bainitic transformation zone annealing at this temperature for the time necessary to complete the bainitic transformation, and, finally cooling to ambient temperature. It allows the formation of the nanobainite composed of bainitic ferrite plates of nanometric thickness separated by thin layers of the carbon-enriched retained austenite [1,4].

For some applications (machine - building industry, tool industry) the hardness of nanobainitic steels is too low, which excludes the use of these attractive steel grades. In this work, we have assumed that greater hardness and abrasion resistance can be achieved through the formation in steel a nanobainitic martix containing highly dispersed carbides. Grained carbides will significantly increase hardness and wear resistance. The aim of this work was to create carbide free bainitic matrix containing hard carbides through specially designed heat treatment. The two types of heat treatment is designed and the influence of the quantity and distribution of carbides precipitation on the bainitic transformation process is determined. 


\section{EXPERIMENTAL}

\subsection{Material}

The chemical composition of the steel investigated in this study is given in Table 1.

Table 1 Chemical composition of 90SiCrMn6-4 steel

\begin{tabular}{|c|c|c|c|c|c|c|c|c|c|c|c|}
\hline Element & $\mathrm{C}$ & $\mathrm{Mn}$ & $\mathrm{Si}$ & $\mathrm{P}$ & $\mathrm{S}$ & $\mathrm{Cr}$ & $\mathrm{Ni}$ & $\mathrm{Mo}$ & $\mathrm{W}$ & $\mathrm{V}$ & $\mathrm{Cu}$ \\
\hline Weight (wt\%) & 0.90 & 0.40 & 1.32 & 0.011 & 0.02 & 1.05 & 0.016 & 0.03 & 0.01 & 0.01 & 0.10 \\
\hline
\end{tabular}

It can be noticed that the investigated steel contained about $1.35 \mathrm{wt} . \%$ of silicon which prevents the precipitation of carbides during bainitic transformation. The addition of Si together with increased content of carbon ( $0.9 \mathrm{wt} . \%)$ are essential for obtaining bainitic nanostructure in the steel. Furthermore, a low content of alloying elements makes $90 \mathrm{SiCrMn6-4}$ steel relatively cheap.

\subsection{Heat treatment}

In order to properly design the heat treatment parameters, the kinetics of phase transformations in steel was determined through dilatometric tests performed in Bähr DIL $508 \mathrm{~L}$ dilatometer. Cylindrical samples with a diameter of $\phi=3 \mathrm{~mm}$ and drilled $4 \mathrm{~mm} \times 3 \mathrm{~mm}$ and height $\mathrm{h}=10 \mathrm{~mm}$ were used for the tests. The recording of extension changes, as a function of time in different temperatures, was carried out using the DIL805L PRO program, which is connected with the dilatometer. As a result, a TTT (Time-Temperature-Transformation) diagram was constructed. To determine characteristic temperatures of phase transformations, steel samples were heated to $1050{ }^{\circ} \mathrm{C}$ at the heating rate of $2{ }^{\circ} \mathrm{C} / \mathrm{min}$. and then cooled to room temperature. The critical temperatures were determined from the diagrams recorded during the cooling. The heat treatments were also conducted in a dilatometric furnace.

The aim of the research was to investigate the influence of the quantity and distribution of carbide precipitations on the bainitic transformation process that occurs in 90SiCrMn6-4 steel. In order to obtain samples with different carbides volume fraction, distribution and morphology, the annealing at the temperature between $\mathrm{Ac}_{1 \mathrm{k}}$ and $A c_{c m}$ was performed $\left(A c_{c m}\right.$ is the boundary temperature for austenite - secondary cementite equilibrium, below which cementite starts to dissolve; $A_{c_{1 k}}$ is the temperature of the end pearlitic transformation). Two types of heat treatments leading to a variable amount and morphology of carbide precipitates were carried out. The heat treatment routes designed in this work followed the sequence displayed in Figure 1.

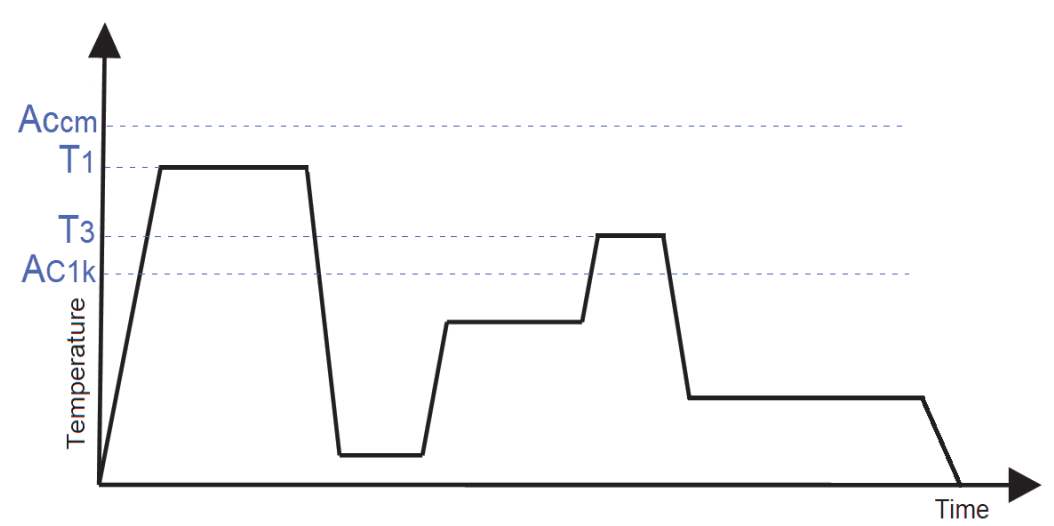

Figure 1 a) The scheme of the first heat treatment

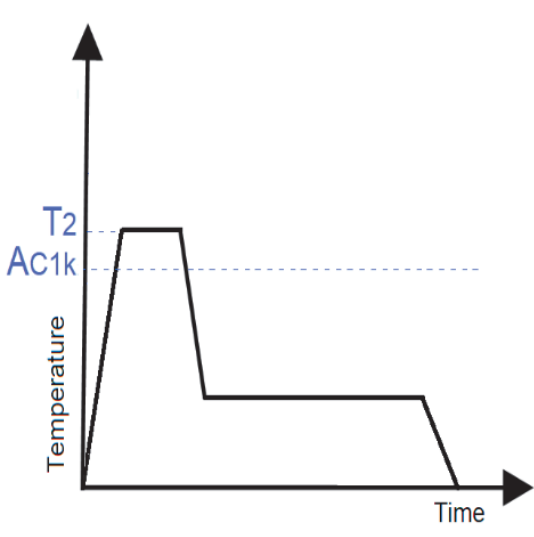

Figure $1 \mathrm{~b}$ ) the second heat treatment 
The first stage of first treatment consisted of heating the steel to austenitizing temperature $T_{1}\left(960{ }^{\circ} \mathrm{C}\right)$ lying about $20-30{ }^{\circ} \mathrm{C}$ below $\mathrm{Ac}_{\mathrm{cm}}$ temperature, thereby causing a significant dissolution of the carbides (mainly cementite). Then, steel samples were quenched to room temperature, and then tempered $\left(\right.$ at $500{ }^{\circ} \mathrm{C}, 550{ }^{\circ} \mathrm{C}$ and $\left.600{ }^{\circ} \mathrm{C}\right)$. Afterwards, the samples were heated to a temperature $T_{3}\left(880{ }^{\circ} \mathrm{C}\right)$ lying $20-30{ }^{\circ} \mathrm{C}$ above the $\mathrm{Ac}_{1 \mathrm{k}}$ temperature. The next stage involved the nanostructuring process that consisted of isothermal quenching of the samples at bainitic transformation temperature. For this purpose, steel was quenched from the temperature $T_{3}$ to a temperature lying about $20-30{ }^{\circ} \mathrm{C}$ above the $M_{s}$ i.e.: martensite start temperature. In this variant of heat treatment the additional cementite particle precipitated during tempering. The computer simulations using the commercial software JMatPro showed, that only cementite can be formed in steel at used temperature range. The first stage of the second treatment consisted in heating the samples to austenitizing temperature $\mathrm{T}_{2}\left(20-30^{\circ} \mathrm{C}\right.$ above $\mathrm{Ac}_{1 \mathrm{k}}$ temperature), which resulted in obtaining of austenite and carbides, which did not dissolve during austenitization. The second stage, similarly as in the first treatment, involved bainitic nanostructuring process that was performed at $20-30{ }^{\circ} \mathrm{C}$ above the $\mathrm{M}_{\mathrm{s}}$ temperature. The duration of the individual processing steps has been determined experimentally on the basis of registered dilatometric curves.

\subsection{The characterization of microstructure}

The obtained microstructures were examined with the use of Light Microscopy (LM). Thin foils, cut from samples after bainitic nanostructuring processes, were subjected to the microstructural observations using JEOL 1200EX Transmission Electron Microscope (TEM), operated at $120 \mathrm{kV}$, to reveal the quantity and distribution of carbide precipitates in steel. Additionally, the thickness of the ferrite plates and the austenite layers was determined with the following formula:

$$
d=\frac{2}{\pi} L
$$

where: $d$ - the real thickness of the ferrite plates or austenite layers and $L$ - the width of the ferrite plates of the austenite layers measured on the TEM image [6]. The measurements of the volume fraction of the austenite were made by the magnetic saturation method.

\subsection{The characterization of hardness}

Hardness in Vickers scale was measured using the ZWICK/ROELL testing machine. The applied load was $19.6 \mathrm{~N}$.

\section{RESULTS}

\subsection{Selection of austenitization temperature and time}

The $\mathrm{Ac}_{\mathrm{cm}}$ and $\mathrm{Ac}_{1 \mathrm{k}}$ temperatures were $985{ }^{\circ} \mathrm{C}$ and $860^{\circ} \mathrm{C}$ respectively. Consequently, to maintain a certain fraction of undissolved carbides, the austenitization was carried out at $T_{1}=960{ }^{\circ} \mathrm{C}$ and $\mathrm{T}_{2}=880{ }^{\circ} \mathrm{C}$. The use of different austenitizing temperatures allowed differentiation of the content and special distribution of carbides. During the austenitizing, a significant increase of the sample length was initially observed in the time-elongation curve. After reaching a maximum, the elongation begins to decline, which may indicate the dissolution of carbides. The value of time corresponding to the maximum elongation of the sample before the subsequent decrease in elongation was taken as the duration of the austenitizing process. For the sample austenitized at $\mathrm{T}_{1}=960^{\circ} \mathrm{C}$ and $\mathrm{T}_{2}=880^{\circ} \mathrm{C}$, the austenitizing time was determined for $8 \mathrm{~min}$ and $10 \mathrm{~min}$ respectively. The values of Ms temperatures after the short ( $8 \mathrm{~min}$ and $10 \mathrm{~min}$ respectively) and long (1.5 h) austenitization time were compared. The shortening of the austenitizing time caused an increase in Ms temperature from $250^{\circ} \mathrm{C}$ to $320{ }^{\circ} \mathrm{C}$ for $\mathrm{T}_{1}=960{ }^{\circ} \mathrm{C}$ and an increase from $220{ }^{\circ} \mathrm{C}$ to $270{ }^{\circ} \mathrm{C}$ for $\mathrm{T}_{2}=880{ }^{\circ} \mathrm{C}$. Nanstructurization process 
on the steel was conducted. For this purpose, steel was annealed at $20-30{ }^{\circ} \mathrm{C}$ above the $\mathrm{M}_{\mathrm{s}}$ temperature. The austempering parameters were determined experimentally based on dilatometric curves. The austempering temperature and time values are summarized in the Table 2 below.

Table 2 Heat treatment parameters

\begin{tabular}{|c|c|c|c|c|c|c|c|c|c|}
\hline & \multicolumn{2}{|c|}{ Austenitization } & \multirow{2}{*}{ Quenching } & \multicolumn{2}{|c|}{ Tempering } & \multicolumn{2}{|c|}{ Austenitization } & \multicolumn{2}{|c|}{ Austempering } \\
\hline & $\mathrm{T}\left({ }^{\circ} \mathrm{C}\right)$ & $t(\min )$ & & $\mathrm{T}\left({ }^{\circ} \mathrm{C}\right)$ & $t(\min )$ & $\mathrm{T}\left({ }^{\circ} \mathrm{C}\right)$ & $t(\min )$ & $\mathrm{T}\left({ }^{\circ} \mathrm{C}\right)$ & $t(h, \min )$ \\
\hline 960_500 & 960 & 8 & + & 500 & 90 & 880 & 10 & 310 & $9 \mathrm{~h}$ \\
\hline 960550 & 960 & 8 & + & 550 & 90 & 880 & 10 & 335 & 7h50" \\
\hline $960 \quad 600$ & 960 & 8 & + & 600 & 90 & 880 & 10 & 290 & $14 \mathrm{~h} 5^{\circ}$ \\
\hline 880 & 880 & 10 & - & - & - & - & - & 290 & $12 \mathrm{~h} 45^{\circ}$ \\
\hline
\end{tabular}

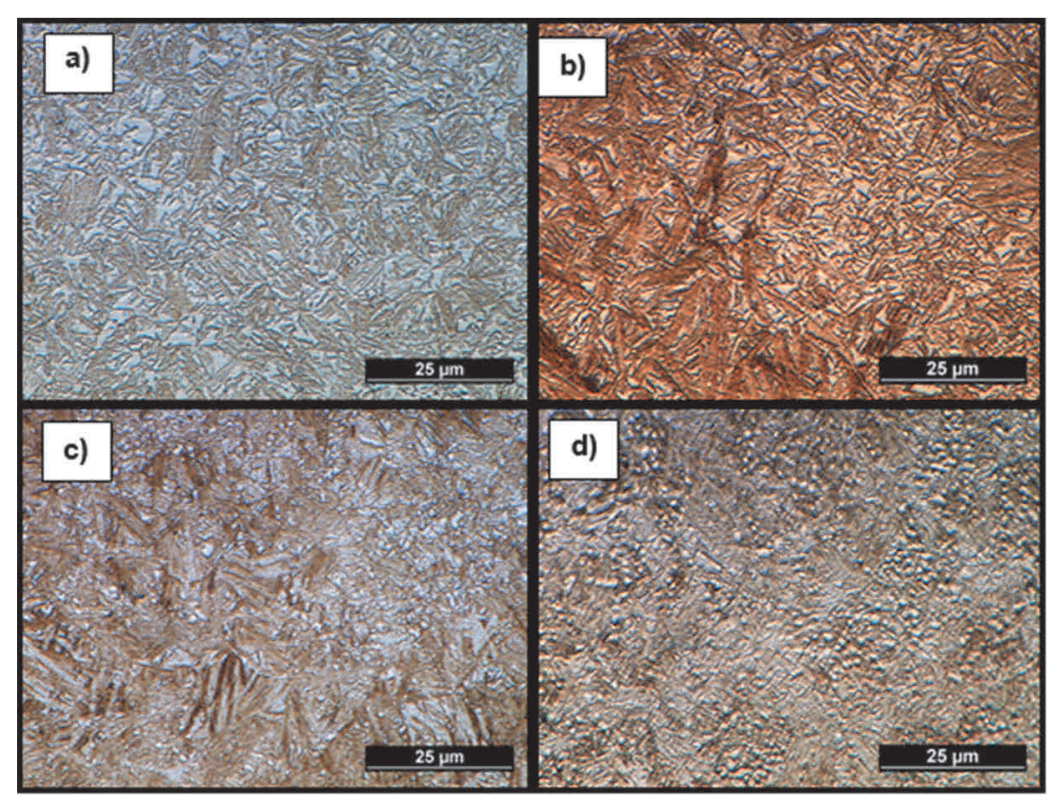

Figure 2 LM figures of microstructure obtained by heat treatment of 90SiCrMn6-4 steel after a) the 960_500 procedure, b) the 960_550 procedure, c) the 960_600 procedure, d) the 880 procedure

\subsection{Microstructure}

Observations made with the use of light microscope revealed that the microstructure after both variants of heat treatments led to obtaining different distributions of carbides in 90SiCrMn6-4 steel (Figure 2). The first variant of heat treatment (regardless of tempering temperature, Figures $2 \mathbf{a}, \mathbf{b}, \mathbf{c}$ ) resulted in a microstructure composed of retained austenite and bainitic ferrite plates which formed groups or packages. The ferritic bainite plates were either parallel to each other or arranged at different angles to each other. An increase in the tempering temperature resulted in increase of the size of carbides and decrease of areas of the retained austenite. The microstructure of sample after second heat treatment variant (Figure 2d) contains clearly visible, undissolved, relatively large carbides.

The microstructure, formed in 90SiCrMn6-4 steel after two selected heat treatments (marked with symbols: 960_500 and 880) was analysed by TEM. Typical images of the microstructure are shown in Figure 3 . The matrix of steel after the 960_500 procedure was composed of bainitic ferrite plates surrounded by retained austenite. The thickness of bainitic ferrite plates varied between $50 \mathrm{~nm}$ and $248 \mathrm{~nm}$ (the mean value was 119 $\mathrm{nm}$ ) and the thickness of austenite layers varied between $10 \mathrm{~nm}$ and $90 \mathrm{~nm}$ (the mean thickness was $37 \mathrm{~nm}$ ). The volume fraction of retained austenite was $37.2 \% \pm 2.7 \%$. Detailed TEM observations of the steel 
microstructure after the first variant of heat treatment confirmed the presence of some secondary carbides (Figure $3 \mathrm{a}$ ), which did not dissolve during austenitizing. The fine spherical carbides which formed clusters were also present (Figures $\mathbf{3} \mathbf{a}, \mathbf{b}$ ). In a microstructure obtained after second heat treatment marked with symbol 880 , the bainitic ferrite plates and austenite layers had more differentiate size as compared to those which were present in the microstructure after first heat treatment (960_500). The thickness of ferrite plates varied between $16 \mathrm{~nm}$ and $306 \mathrm{~nm}$ (with the average value of $111 \mathrm{~nm}$ ). In this microstructure austenite was present in form of layers between the ferrite laths and in form of blocks. The austenite volume fraction was $14.9 \% \pm 2 \%$, which was significantly less than in the case of the first variant of heat treatment. The thickness of the austenite layers varied between $9 \mathrm{~nm}$ and $159 \mathrm{~nm}$ (with the mean value of $61 \mathrm{~nm}$ ). This microstructure contained also higher density of secondary carbides, which remained after the austenitizig at $880^{\circ} \mathrm{C}$ below the boundary temperature for austenite (the temperature at which carbides begin to dissolve $-985^{\circ} \mathrm{C}$ ) in this steel (Figure 3d).

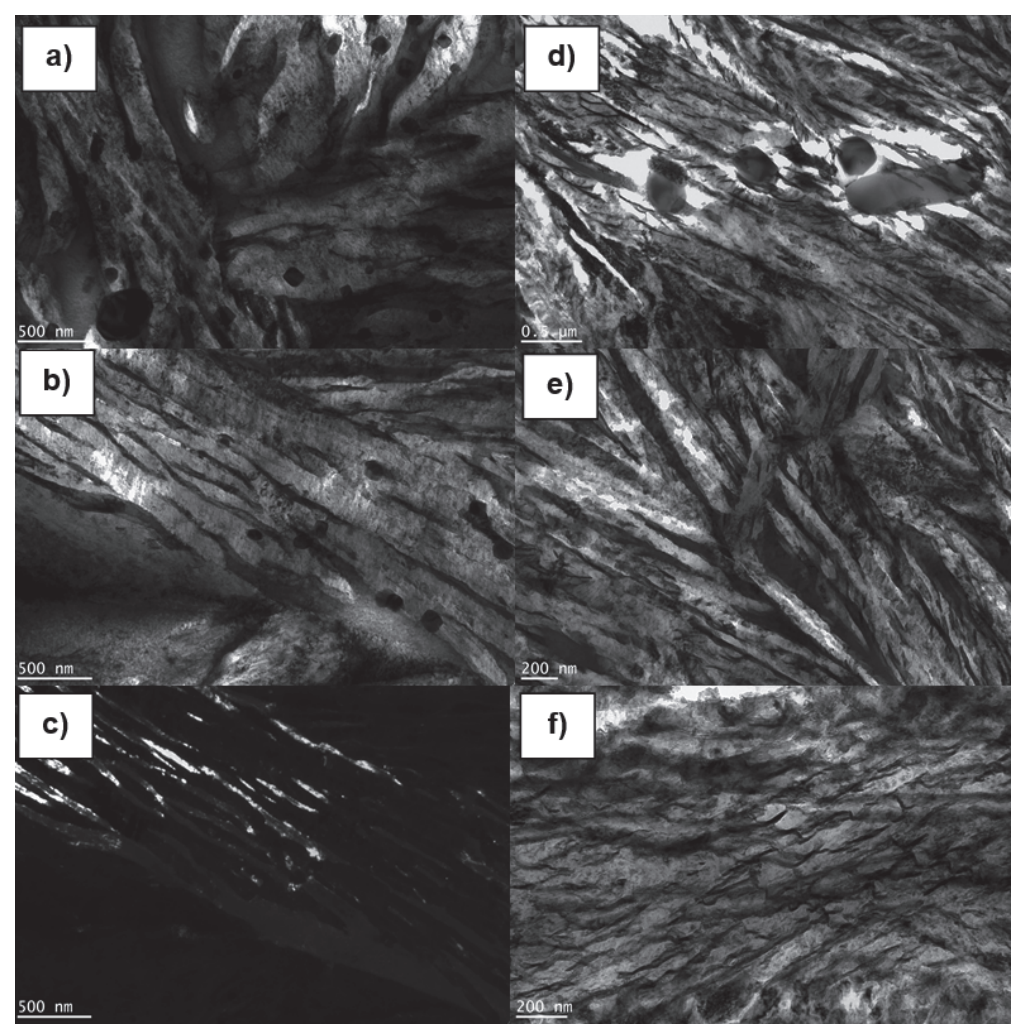

Figure 3 TEM image of microstructure of 90SiCrMn6-4 steel after nanostructuring processes marked with symbols: a), b), c) - 960_500, d), e), f) - 880

\subsection{Hardness}

Hardness and volume fraction of retained austenite data for the tested steel samples obtained in various heat treatment parameters are shown in Figure 4. Hardness of the tested steel after first type of heat treatment (marked with symbols: 960_500, 960_550 and 960_600) increased with an increase of tempering temperature. The increase in hardness is correlated with the decrease in austenite content. Austenite has a lower hardness compared to bainitic ferrite, so increasing the austenite content in the microstructure leads to a decrease in hardness of steel. The hardness of steel treated according to the 880 variant is slightly higher than the hardness obtained for the 960_600 variant. It could be caused by more refined microstructure obtained in the 880 variant as a result of applying lower austempering temperature. As may be observed in Figure 4, the austenite volume content has a tendency to decrease with the increase of the tempering temperature. The maximum volume fraction of retained austenite $-37.2 \% \pm 2.7 \%$ was reached after first type of heat treatment 
using the lowest tempering temperature $\left(500{ }^{\circ} \mathrm{C}\right)$. The application of higher tempering temperature led to higher volume fraction of carbides in the microstructure and thus to lower carbon in the austenite which is necessary to stabilize it during austempering. As a result, smaller volume fraction of retained austenite was observed in variants where more carbides occured in the microstructure.

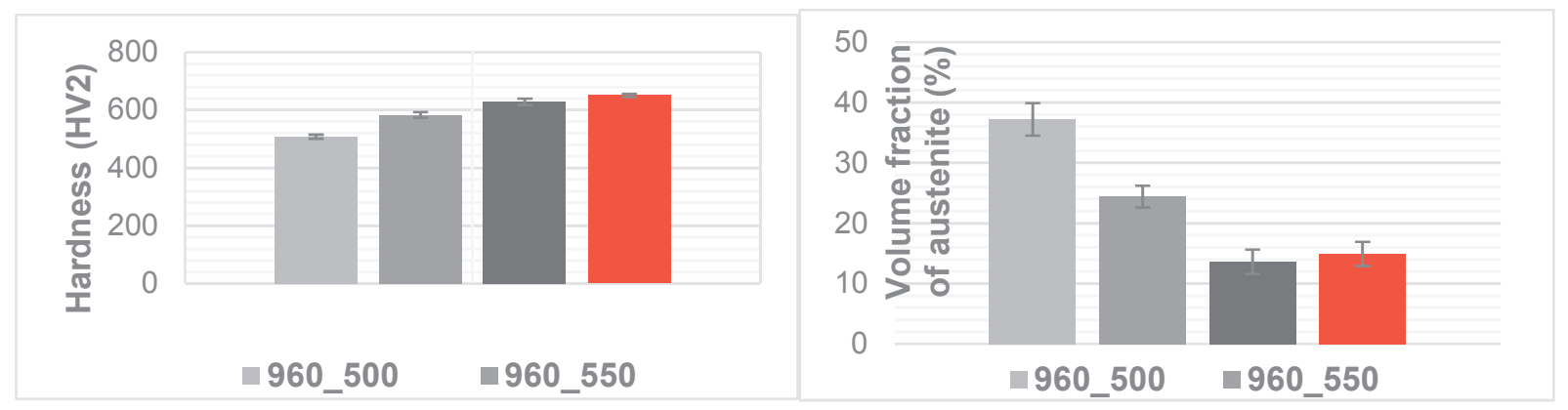

Figure 4 Hardness and volume fraction of retained austenite data for samples of 90SiCrMn6-4 steel after analysed heat treatments

\section{CONCLUSION}

As a result of specially designed heat treatments of 90SiCrMn6-4 the microstructure with carbide precipitates submerged in a carbide free bainitic matrix was obtained. The thickness of bainitic ferrite plates was submicron or nanometric depending on the heat treatment used. The austenite was in the form of thin, nanometric layers and in form of blocks. Depending on a heat treatment the retained austenite content in the microstructure varied in a wide range, which affected steel hardness. The obtained results show that by changing the content and morphology of carbides it is possible to control the phase composition and hardness of the steel.

\section{ACKNOWLEDGEMENTS}

The results presented in this work have been obtained within the project NanoCarbain (contract no. LIDER/12/0040/L-9/17/NCBR/2018). The project is financed by the National Centre for Research and Development under the LIDER IX program.

\section{REFERENCES}

[1] BELADI, H., ADACHI, Y., TIMOKHINA, I. and HODGSON, P.D. Crystallographic analysis of nanobainitic steels. Scripta Materialia. 2009. vol. 60, pp. 455-458.

[2] CABAlLERO, F. G., BADESHIA, H. K. D. H. and MAWELLA, K. J. A. Very strong low temperature bainite. Materials Science and Technology. 2002. vol. 18, pp. 279-284.

[3] GARCIA-MATEO, C., CABALLERO, F. G. and BADESHIA, H. K. D. H. Development of hard bainite. ISIJ International. 2003. vol. 43, no. 8, pp. 1238-1243.

[4] ŚWIĄTNICKI, W.A., POBIEDZIŃSKA, K., SKOŁEK, E., GOŁASZEWSKI, A., MARCINIAK, Sz., NADOLNY, Ł. and SZAWŁOWSKI, J. Otrzymywanie struktury nanokrystalicznej w stalach przy wykorzystaniu przemiany bainitycznej. Inżynieria Materiałowa. 2012. vol. XXXIII, no. 6, pp. 524-529.

[5] BHADESHIA, H.K.D.H., Nanostructured bainite. Proc. R. Soc. A. 2010. vol. 466, pp. 3-18.

[6] CHANG, L. C. and BHADESHIA, H. K. D. H. Austenite films in bainitic microstructures. Materials Science and Technology. 1995. vol. 11, pp. 874-881. 